\title{
The impact of repeated water soaking of cereal straw on the slagging index and the formation of deposits on heating surfaces of power boilers
}

ABSTRACT: The article presents the results of the analysis of straw obtained from ripening wheat, which was subjected to four water soaking cycles in demineralized water. The soaking was carried out under laboratory conditions at $20^{\circ} \mathrm{C}$. As a result, part of mineral matter, including a significant amount of alkaline sodium and potassium salts and substances containing sulfur and phosphorus, was washed out. The process of soaking has a great impact on the chemical composition of ash obtained from water-treated straw, which increased its acidity. The $\mathrm{Na}_{2} \mathrm{O}$ content in the analyzed ash has decreased by $78 \%$, while the $\mathrm{K}_{2} \mathrm{O}$ content has decreased by $60 \%$. In turn, the content of water-insoluble, acid-forming $\mathrm{SiO}_{2}$ has increased by $80 \%$. As a consequence, a positive change in the values of indices, on the basis of which the tendency of straw to slagging and deposit formation during the combustion and gasification processes is assessed, has been observed. Already after the second water soaking cycle it became apparent, based on the $A I$ alkali index, that the examined fuel should not cause difficulties resulting from the increased intensity of use of the boiler during the combustion process. Meanwhile, the value of the $B A I$ bed agglomeration index was considered to be safe, indicating a low possibility of bed agglomeration during the combustion or fluidized bed gasification, after the third water soaking cycle. The third of the analyzed indices, the $F u$ fouling index, did not indicate any tendency to deposit formation during the combustion; however, four water soaking cycles reduced its initial value by $80 \%$. The last of the analyzed indexes, the $S R$, slag viscosity index did not change its value during the experiment, which, both for the raw straw and

\footnotetext{
${ }^{1}$ AGH University of Science and Technology, Faculty of Energy and Fuels, Department of Fuels Technology, Kraków, e-mail: rozwadow@agh.edu.pl, tadeusz.dziok@agh.edu.pl
} 
after subsequent soaking cycles, indicated that the fuel should have a low tendency to accumulate slag during the combustion process.

KEYWORDS: cereal straw, water soaking, ash, alkali, slagging

\section{Introduction}

Plant biomass of agricultural origin and forest biomass are seen as difficult to integrate into the power system (Skręta 2012; Malone et al. 2014). This opinion stems from the problems related to biomass combustion and gasification processes. The most commonly mentioned disadvantages are corrosive properties, a high tendency to slagging of boiler parts, and the susceptibility to bed agglomeration in fluidized bed combustion and gasification. These negative characteristics result from the high concentration of alkaline compounds and chlorine contained mainly in the mineral part of the plant biomass (Dzik and Rozwadowski 2012; Ściążko et al. ed. 2007; Hansen et al. 2000; Persson et al. 2007). However, the unfavorable properties of plant biomass can be limited by water soaking. This can be obtained by leaving straw in the field after harvesting. Fresh (socalled "yellow") straw is characterized by significantly worse energy properties; however, under the influence of atmospheric precipitation, it transforms into so-called gray straw, which is less corrosive and characterized by lower tendency to slagging. Repeated soaking of straw in water can effectively reduce its chemical aggressiveness; water soaking of straw before feeding it to the boiler has already been reported (Rybak 2006; Jenkins et al. 1996; Davidsson et al. 2002). The discussed biomass needs to be dried, but the possibility of longer operation of boiler equipment is the reason why the energy used for drying the product is cost-effective.

The process of water soaking of green biomass (meadow grass) in order to improve its energy properties as a raw material for the production of solid fuel and proenzyme used for biogas production is also effectively carried out with the use of innovative IFBB technology (Integrated Generation of Solid Fuel and Biogas from Biomass) (Bühle et al. 2014; Golinski et al. 2014; Richter et al. 2011).

The aim of the article was to examine the impact of repeated water soaking on the chemical composition of the mineral matter of plant biomass and the ability to limit the formation of deposits during the combustion process. The appropriate intervention in the chemical structure of the biomass would possibly expand the list of renewable solid fuels with the currently underestimated green biomass, obtained during the vegetation period of plants.

The paper is the continuation of the work published in 2017 in Polityka Energetyczna Energy Policy Journal (Rozwadowski and Dziok 2017). 


\section{Research scope and methodology}

The straw of winter wheat, which was collected in the final stage of ripening (hardening of the grain), was selected for the analysis. Freshly harvested wheat straw without ears was cut into chaffs $0-10 \mathrm{~mm}$. Part of the resulting biomass was subjected to repeated soaking carried out in laboratory conditions. The rest was used to prepare the sample for the analysis of the properties of the resulting biomass. The repeated water soaking process was carried out with demineralized water at $20^{\circ} \mathrm{C}$, using the same ratio of water weight to the weight of dry chaff. The time of each soaking cycle, during which the entire chaff was immersed in water, was 1 hour. After this time, the biomass was filtered through a thick sieve; the water was separated from the biomass, which was dried at $50^{\circ} \mathrm{C}$ in order to prepare the analytical sample. The rest of the chaff was subjected to the soaking process with an appropriate amount of fresh deionized water. The soaking, draining, and drying processes were carried out four times.

During the conducted experiment, the following analyzes and determinations were made. When it comes to biomass examination, a proximate analysis of raw and soaked chaff samples was carried out, which allowed determining:

$\checkmark$ The moisture content according to the EN 14774:2009 standard.

$\checkmark$ The volatile matter content according to the EN 15148:2009 standard.

$\checkmark$ The ash content according to the EN 14775:2009 standard (the incineration temperature of $\left.815^{\circ} \mathrm{C}\right)$.

$\checkmark$ The gross calorific value according to the EN 14918:2009 standard.

The analysis of the chemical composition of ash was carried out using a PerkinElmer OPTIMA 7300 DV ICP OES. The ash samples for these tests were obtained from the combustion of raw and soaked chaff in a muffle furnace at $815^{\circ} \mathrm{C}$.

The tendency of straw to deposit formation during the combustion process, a critical parameter of this part of the analysis, was assessed using indices cited in the literature (Pronobis 2005; Mac an Bhaird et al. 2014; Werle 2013) calculated on the basis of the chemical composition of ash obtained in laboratory conditions from raw and soaked wheat chaff. This tendency, the so-called "slag forming potential" was examined using the following biomass indices:

$\checkmark$ The alkali index $A I$,

$\checkmark$ The fouling Index $F_{u}$,

$\downarrow$ The slag viscosity index $S_{R}$,

$\checkmark$ The bed agglomeration index $B A I$.

The alkali index $A I[\mathrm{~g} / \mathrm{MJ}]$ was calculated based on the following formula (Blomberg 2007),

$$
A l=\frac{N a_{2} \mathrm{O}+\mathrm{K}_{2} \mathrm{O}}{Q_{s}^{d}}
$$


Where:

$$
\begin{aligned}
\mathrm{Na}_{2} \mathrm{O} \text { and } \mathrm{K}_{2} \mathrm{O}- & \text { the content of sodium and potassium oxides in biomass }[\mathrm{g} / \mathrm{kg}] \\
& \text { (dry basis). } \\
Q_{S}{ }^{\mathrm{d}} & - \text { gross calorific value }[\mathrm{MJ} / \mathrm{kg}] \text { (dry basis). }
\end{aligned}
$$

If the $A I$ index exceeds $0.17 \mathrm{~g} / \mathrm{MJ}$, the fuel should be considered as dangerous because of a high tendency to slagging; when the mentioned index exceeds $0.34 \mathrm{~g} / \mathrm{MJ}$, the tendency is very high (Rybak 2006; Mac an Bhaird et al. 2014).

The values of the $F u$ index were calculated using the following formula:

$$
\mathrm{Fu}=c_{m}\left(\mathrm{Na}_{2} \mathrm{O}+\mathrm{K}_{2} \mathrm{O}\right)
$$

In which:

$$
c_{m}=\frac{\mathrm{Fe}_{2} \mathrm{O}_{3}+\mathrm{CaO}+\mathrm{MgO}+\mathrm{Na}_{2} \mathrm{O}+\mathrm{K}_{2} \mathrm{O}+\mathrm{P}_{2} \mathrm{O}_{5}}{\mathrm{SiO}_{2}+\mathrm{Al}_{2} \mathrm{O}_{3}+\mathrm{TiO}_{2}}
$$

Where:

$\mathrm{Fe}_{2} \mathrm{O}_{3}, \mathrm{CaO}, \mathrm{MgO}, \ldots$. - the content of individual oxides in fuel ash [\%].

If (Ściążko et. al. ed. 2007):

$F u \leq 0.6$ - no tendency to deposit formation, $0.6<F u \leq 40$ - the examined fuel has a high tendency to deposit formation, $F u>40$ - a very high tendency to form deposits on the heating surfaces of the boiler.

The next analyzed index, $S_{R}$, was the slag viscosity index calculated on the basis of the following formula:

$$
S_{R}=\frac{\mathrm{SiO}_{2} \cdot 100}{\mathrm{SiO}_{2}+\mathrm{Fe}_{2} \mathrm{O}_{3}+\mathrm{CaO}+\mathrm{MgO}}
$$

Where:

$\mathrm{Fe}_{2} \mathrm{O}_{3}, \mathrm{CaO}, \mathrm{MgO}$, and $\mathrm{SiO}_{2}$ - the content of individual oxides in the fuel ash [\%].

When the slag viscosity index is $S_{R}>72$ the fuel has a low tendency of slagging, the values in the range $72 \geq S_{R}>65$ indicate medium slagging tendency, while $S_{R} \leq 65$ denotes a high slagging tendency (Ściążko et al. ed. 2007).

The agglomeration of the fluidized bed during the combustion and gasification processes was assessed using the $B A I$ (bed agglomeration index) calculated using the following formula (Mac an Bhaird et al. 2014):

$$
\mathrm{BAI}=\frac{\mathrm{Fe}_{2} \mathrm{O}_{3}}{\mathrm{~K}_{2} \mathrm{O}+\mathrm{Na}_{2} \mathrm{O}}
$$


Where:

$\mathrm{Fe}_{2} \mathrm{O}_{3}, \mathrm{Na}_{2} \mathrm{O}$, and $\mathrm{K}_{2} \mathrm{O}$ is the content of individual oxides in fuel ash [\%].

The ash with the BAI index lower than 0.15 has a high tendency for bed agglomeration during combustion or gasification.

\section{The research results and analysis}

Table 1 presents the results of determinations made during the technical analysis of raw and soaked (using demineralized water) straw samples.

TABLE 1. The results of the proximate analysis of straw samples

TABELA 1. Wyniki analizy technicznej próbek z badanej słomy

\begin{tabular}{|l|c|c|c|c|c|}
\hline \multirow{2}{*}{\multicolumn{1}{c|}{ The examined parameter: }} & \multicolumn{5}{|c|}{ Straw type } \\
\cline { 2 - 6 } & raw & $\begin{array}{c}\text { after first } \\
\text { soaking and } \\
\text { drying }\end{array}$ & $\begin{array}{c}\text { after second } \\
\text { soaking and } \\
\text { drying }\end{array}$ & $\begin{array}{c}\text { after third } \\
\text { soaking and } \\
\text { drying }\end{array}$ & $\begin{array}{c}\text { after fourth } \\
\text { soaking and } \\
\text { drying }\end{array}$ \\
\hline The analytical moisture content $\mathrm{M}^{\text {ad }}[\%]$ & 7.6 & 8.2 & 6.3 & 7.5 & 6.1 \\
\hline The ash content $\mathrm{A}^{\mathrm{d}}[\%]$ & 4.1 & 4.0 & 3.8 & 3.9 & 3.6 \\
\hline Volatile matter content $\mathrm{V}^{\mathrm{d}}[\%]$ & 76.76 & 77.03 & 78.70 & 78.84 & 80.07 \\
\hline The gross calorific value $\mathrm{GCV}^{\mathrm{d}}[\mathrm{MJ} / \mathrm{kg}]$ & 19.092 & 19.023 & 18.712 & 18.520 & 18.549 \\
\hline
\end{tabular}

The presented data confirm that water soaking of straw washed out selected components of the mineral matter, the concentration of which, evaluated on the basis of ash content, clearly decreased (Fig. 1).

Water soaking of straw washed away, among others, water-soluble potassium and sodium salts. This is confirmed by the results of the analysis of the content of $\mathrm{K}_{2} \mathrm{O}$ and $\mathrm{Na}_{2} \mathrm{O}$ oxides in ash samples obtained from water-soaked straw presented in Table 2 and Fig. 2.

Systematic reduction of the $\mathrm{SO}_{3}$ and $\mathrm{P}_{2} \mathrm{O}_{5}$ content in ash samples from water-soaked straw, which can be observed in the graphs shown in Fig. 3, suggests that salts containing sulfur and phosphorus were also washed out during the mentioned operation. Meanwhile, based on Fig. 4 it can be concluded that water soaking of straw increased the concentration of $\mathrm{SiO}_{2}$, which is a water insoluble compound.

The biomass tendency to deposit formation in the boiler during the combustion process can be directly determined by the observation of elements of the boiler or by forecasting this tendency using indexes calculated on the basis of the chemical composition of ash. Knowing the disadvantages of both methods, it was decided to estimate the changing "slag forming potential" 


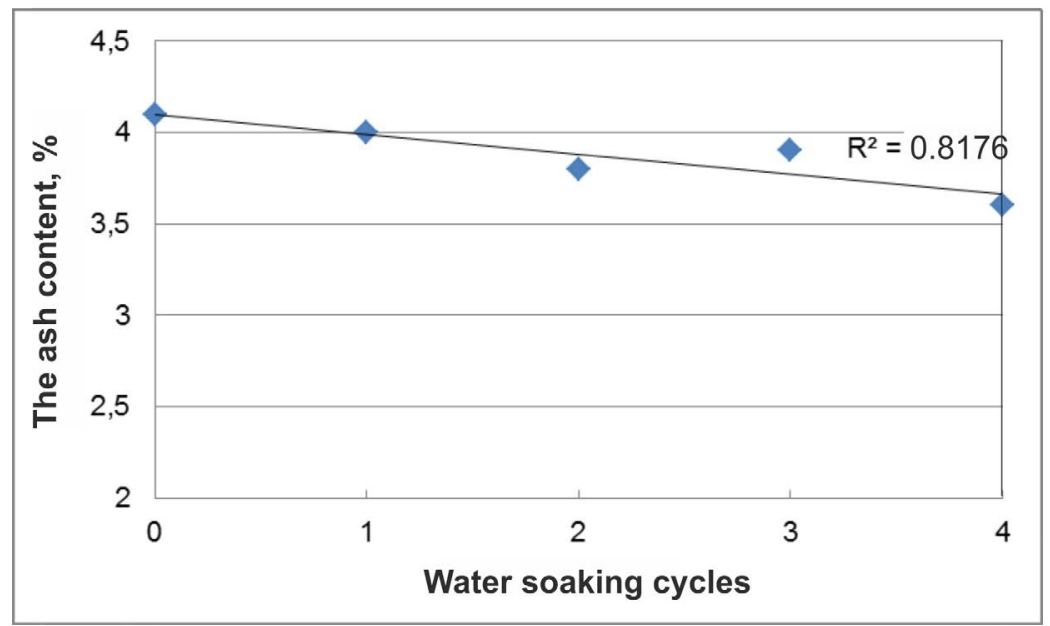

Fig. 1. The change in the ash content of water-soaked straw

Rys. 1. Zmiana zawartości popiołu w próbkach słomy moczonej w wodzie

TABLE 2. The chemical composition of ash obtained from straw samples after subsequent water soaking processes [\%]

TABELA 2. Skład chemiczny popiołu otrzymanego z próbek słomy po kolejnych cyklach moczenia w wodzie [\%]

\begin{tabular}{|c|c|c|c|c|c|}
\hline Oxide type: & Before soaking & $\begin{array}{l}\text { After first soaking } \\
\text { and drying }\end{array}$ & $\begin{array}{l}\text { After second } \\
\text { soaking and } \\
\text { drying }\end{array}$ & $\begin{array}{l}\text { After third } \\
\text { soaking and } \\
\text { drying }\end{array}$ & $\begin{array}{c}\text { After fourth } \\
\text { soaking and } \\
\text { drying }\end{array}$ \\
\hline $\mathrm{Li}_{2} \mathrm{O}$ & 0.0541 & 0.0082 & 0.0271 & 0.0117 & 0.0208 \\
\hline $\mathrm{Na}_{2} \mathrm{O}$ & 2.2960 & 0.3827 & 0.8646 & 0.3429 & 0.4929 \\
\hline $\mathrm{K}_{2} \mathrm{O}$ & 11.1380 & 10.1716 & 6.4478 & 5.2245 & 4.3830 \\
\hline $\mathrm{CaO}$ & 3.0499 & 2.9045 & 3.3035 & 3.1050 & 3.4494 \\
\hline $\mathrm{MgO}$ & 1.3371 & 1.4501 & 1.3748 & 1.4182 & 1.4107 \\
\hline $\mathrm{Fe}_{2} \mathrm{O}_{3}$ & 0.3388 & 0.9135 & 0.8765 & 0.8854 & 0.9797 \\
\hline $\mathrm{B}_{2} \mathrm{O}_{3}$ & 0.0100 & 0.0173 & 0.0158 & 0.0256 & 0.0207 \\
\hline $\mathrm{SO}_{3}$ & 4.8275 & 3.0062 & 2.7685 & 2.3649 & 2.3072 \\
\hline $\mathrm{SiO}_{2}$ & 65.0000 & 71.0000 & 75.5000 & 79.5000 & 80.0000 \\
\hline $\mathrm{P}_{2} \mathrm{O}_{5}$ & 10.7642 & 9.2982 & 7.7108 & 6.0732 & 5.5270 \\
\hline $\mathrm{ZnO}$ & 0.0206 & 0.0184 & 0.0716 & 0.0714 & 0.1207 \\
\hline $\mathrm{Al}_{2} \mathrm{O}_{3}$ & 0.1190 & 0.1389 & 0.3214 & 0.1379 & 0.2237 \\
\hline $\mathrm{Mn}_{2} \mathrm{O}_{5}$ & 0.0638 & 0.0891 & 0.1014 & 0.1051 & 0.1104 \\
\hline $\mathrm{UO}_{3}$ & 0.0000 & 0.0000 & 0.0017 & 0.0000 & 0.0000 \\
\hline $\mathrm{TiO}_{2}$ & 0.0000 & 0.0000 & 0.0000 & 0.0000 & 0.0000 \\
\hline $\mathrm{As}_{2} \mathrm{O}_{5}$ & 0.0008 & 0.0005 & 0.0037 & 0.0020 & 0.0003 \\
\hline $\mathrm{PbO}$ & 0.0015 & 0.0005 & 0.0043 & 0.0028 & 0.0069 \\
\hline $\mathrm{CrO}_{3}$ & 0.0080 & 0.0112 & 0.0158 & 0.0281 & 0.0248 \\
\hline $\mathrm{CdO}$ & 0.0006 & 0.0003 & 0.0004 & 0.0004 & 0.0005 \\
\hline
\end{tabular}

130 


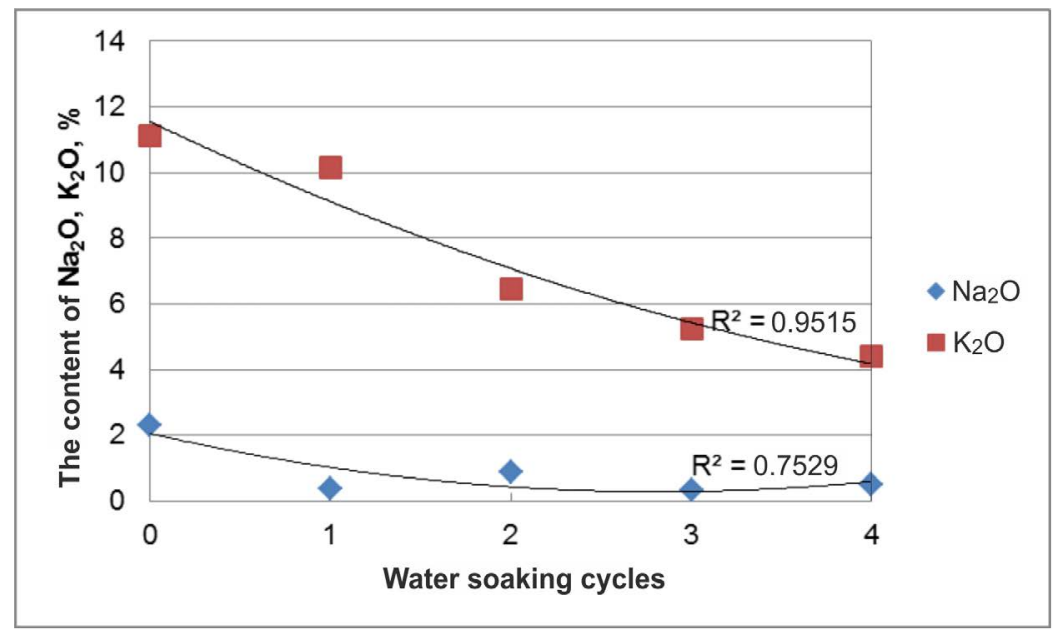

Fig. 2. The change in the $\mathrm{Na}_{2} \mathrm{O}$ and $\mathrm{K}_{2} \mathrm{O}$ content of the ash from water-soaked straw samples

Rys. 2. Zmiana zawartości $\mathrm{Na}_{2} \mathrm{O}$ i $\mathrm{K}_{2} \mathrm{O}$ w popiele z próbek słomy moczonej w wodzie

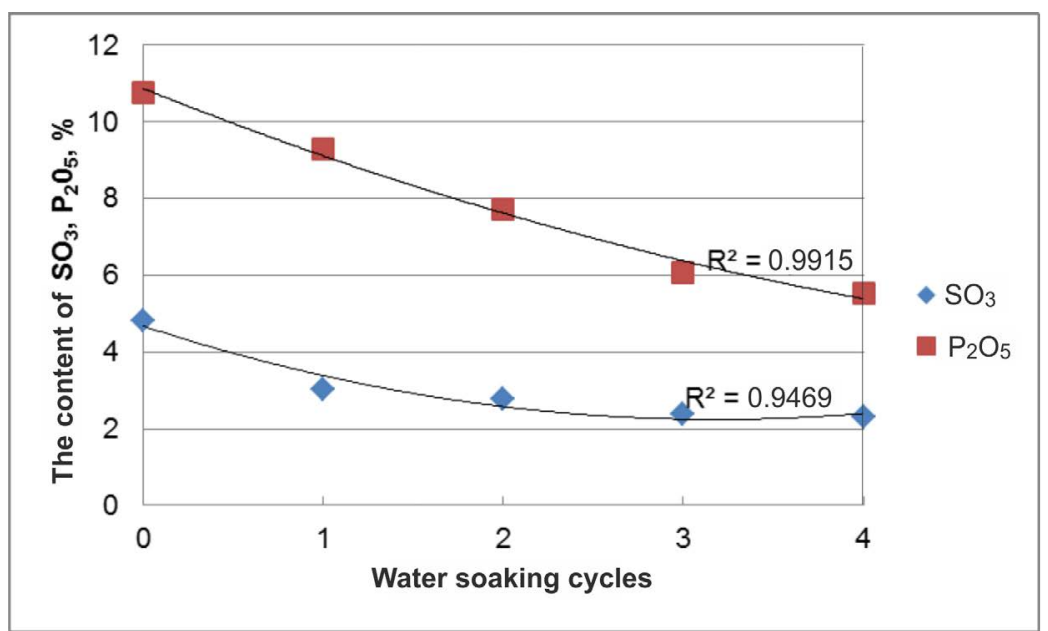

Fig. 3. The change in the $\mathrm{SO}_{3}$ and $\mathrm{P}_{2} \mathrm{O}_{5}$ content of the ash from water-soaked straw

Rys. 3. Zmiana zawartości $\mathrm{SO}_{3}$ i $\mathrm{P}_{2} \mathrm{O}_{5}$ w popiele z próbek moczonej w wodzie słomy

of the soaked biomass using the $A I$ alkali index, $F u$ fouling-Index, $S_{R}$ slag viscosity index, and $B A I$ bed agglomeration index. The indices calculated on the basis of formulas $1-5$ are presented in Table 3. Meanwhile, changes in the $A I, F u$, and $B A I$ indexes after subsequent water soaking cycles are illustrated in graphs in figures 5-7. They show that the repeated soaking process effectively changed the chemical composition of the mineral matter and that the ash obtained from the combustion of water-treated straw was characterized by much more favorable properties. 


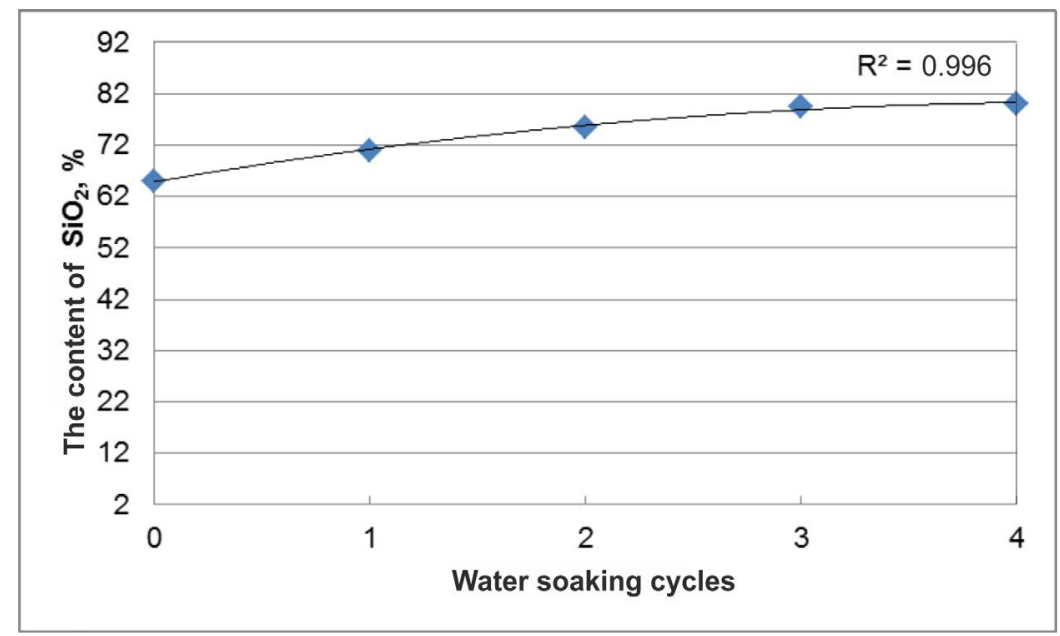

Fig. 4. Changes in the $\mathrm{SiO}_{2}$ content of the ash from water-soaked straw

Rys. 4. Zmiana zawartości $\mathrm{SiO}_{2}$ w popiele z próbek moczonej w wodzie słomy

TABLE 3. The $A I, F u, c_{m}, S_{R}$ and $B A I$ indices calculated for the ash from water-soaked straw

TABELA 3. Wskaźniki $A I, F u, c_{m}, S_{R}$ oraz BAI obliczone dla składu popiołu z próbek moczonej w wodzie słomy

\begin{tabular}{|l|c|c|c|c|c|}
\hline \multirow{2}{*}{\multicolumn{1}{|c|}{ Index name }} & \multicolumn{5}{|c|}{ Straw type } \\
\cline { 2 - 6 } & raw & $\begin{array}{c}\text { after first } \\
\text { soaking and } \\
\text { drying }\end{array}$ & $\begin{array}{c}\text { after second } \\
\text { soaking and } \\
\text { drying }\end{array}$ & $\begin{array}{c}\text { after third } \\
\text { soaking and } \\
\text { drying }\end{array}$ & $\begin{array}{c}\text { after fourth } \\
\text { soaking and } \\
\text { drying }\end{array}$ \\
\hline The $A I$ alkali index [g/MJ] & 0.288 & 0.222 & 0.148 & 0.117 & 0.095 \\
\hline The $F u$ fouling index & 5.9 & 3.6 & 1.7 & 1.2 & 1.0 \\
Index $c_{m}$ & 0.443 & 0.353 & 0.271 & 0.214 & 0.202 \\
\hline The $S_{R}$ slag viscosity index & 93.2 & 93.1 & 93.1 & 93.6 & 93.2 \\
\hline The $B A I$ bed agglomeration index & 0.025 & 0.087 & 0.120 & 0.160 & 0.201 \\
\hline
\end{tabular}

The $A I$ alkali index of the ash from straw was already below $0.17 \mathrm{~g} / \mathrm{MJ}$ (dotted line in Fig. 5), which is considered as a safe value when it comes to the tendency of fuel to slagging in the boiler during the combustion process (Rybak 2006).

Unfortunately, while four water soaking cycles significantly reduced (by over $80 \%$ in relation to the initial value) the Fouling-Index $F u$, the mentioned index was still too high to be considered safe from the point of view of boiler slagging $(\mathrm{Fu}<0.6)$. This is presented in the graph in Fig. 6.

In the third analyzed index, the slag viscosity index $S_{R}$ did not change clearly as a result of water soaking processes. The calculated index, i.e. the amount of deposits formed during the combustion process is considered to be safe (Ściążko et al. ed. 2007). 


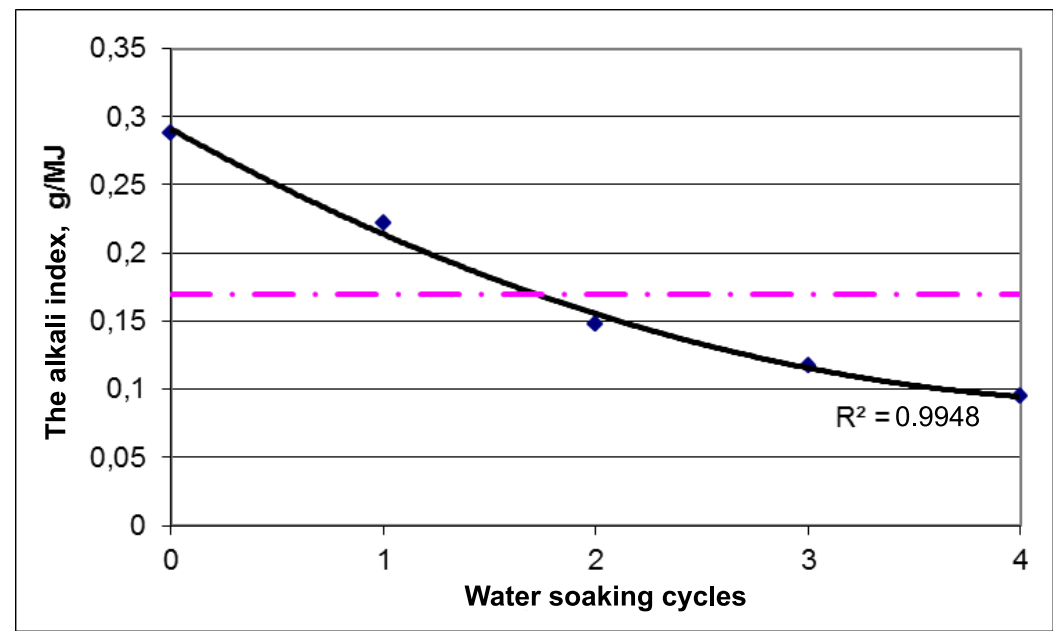

Fig. 5. Changes in the $A I$ alkali index after repeated water soaking of straw

Rys. 5. Zmiana wartości indeksu alkaliczności $A I$ pod wpływem wielokrotnego moczenia słomy wodą

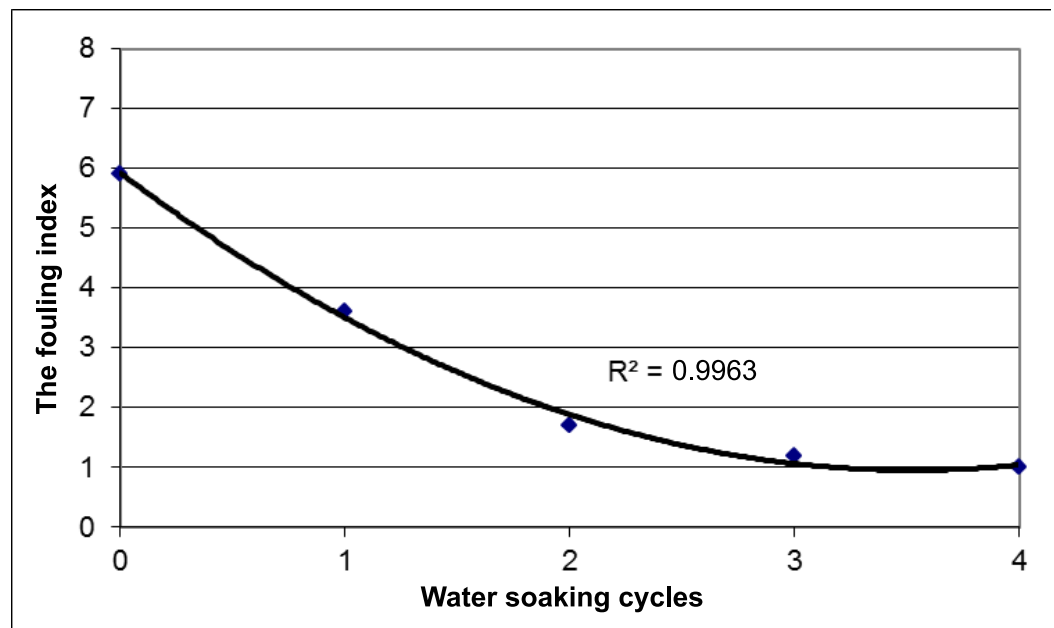

Fig. 6. Changes in the $F u$ fouling index after repeated water soaking of straw

Rys. 6. Zmiana wartości wskaźnika Fouling-Index $F u$ pod wpływem wielokrotnego moczenia słomy wodą

Fig. 7 illustrates the impact of water soaking of straw on the $B A I$ index, which is used to assess the bed agglomeration in fluidized bed reactors and boilers. This suggests that the three water soaking cycles effectively increased the $B A I$ index to above 0.15 , which is considered a safe value. 


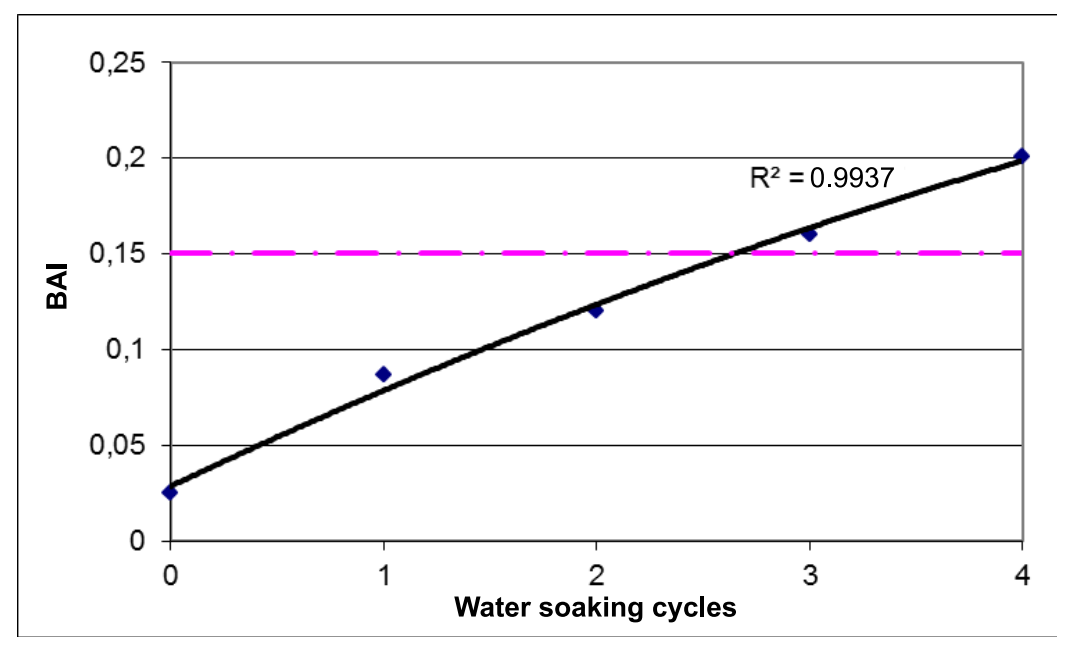

Fig. 7. Changes in the bed agglomeration index $B A I$ after repeated water soaking of straw

Rys. 7. Zmiana wartości wskaźnika aglomeracji złoża $B A I$ pod wpływem wielokrotnego moczenia słomy wodą

\section{Conclusions}

The conducted analysis, inspired by natural phenomena occurring after harvesting, has shown that the repeated water-soaking of wheat straw has a positive effect on the quantity and chemical composition of the obtained ash. The water-soaking of straw washed out water soluble salts; as a result, the ash content determined in the water-soaked samples clearly decreased. Four water soaking cycles allowed the ash content to be decreased by $12 \%$ compared to the initial value.

The repeated water soaking cycles significantly affected the chemical composition of ash resulting from water-treated samples, reducing the concentration of alkali oxides of sodium and potassium. Their concentration in ash decreased by: in the case of $\mathrm{Na}_{2} \mathrm{O}$ by $78 \%$, while for $\mathrm{K}_{2} \mathrm{O}$ by over $60 \%$ compared to the initial content of non-soaked straw in the ash. However, the concentration of water-insoluble $\mathrm{SiO}_{2}$ increased by $23 \%$. The soaking has reduced the content of $\mathrm{SO}_{3}$ and $\mathrm{P}_{2} \mathrm{O}_{5}$ in relation to their content in the straw subjected to the process by 52 and $48 \%$, respectively.

The consequence of changes in the chemical composition of straw as a result of soaking was a clear improvement in the value of most indicators, by means of which the slag forming potential, i.e. the tendency to deposit formation and bed agglomeration during the combustion and gasification processes, was assessed. The analyzed straw subjected to repeated soaking was characterized by a high tendency to slagging boiler parts and bed agglomeration in boilers. The $A Y, F u$, and $B A I$ indices calculated for raw straw were clearly different from those considered 
as safe from the point of view of the correct operation of the mentioned devices. The values of these indexes were gradually improving with the following water soaking cycles. As a result, the values of the $A I$ alkali index and the $B A I$ bed agglomeration index were acceptable (i.e. indicated no tendency to slagging and bed agglomeration) after the second and third soaking cycles, respectively. The soaking process has decreased the third of the analyzed indices, namely the $F u$ fouling index, by over $80 \%$ compared to the initial value. However, the index value after the fourth soaking process, $F u=1.0$, cannot be considered safe, as the safe value for this index, indicating the fuel with no tendency to deposit formation, is $F u \leq 0.6$.

The last of the analyzed parameters, the $S_{R}$ slag viscosity index did not change its value during the experiment, which, both for the raw straw and after subsequent soaking cycles, was about $S_{R}=93$. This index indicates a low tendency of the analyzed fuel to slagging during the combustion process.

In summary, it can be concluded that water soaking of the ripening plant biomass can significantly improve its properties as a fuel. In particular, it can reduce the ash content in the biomass, the amount of alkaline compounds and, as a consequence, minimize the tendency of biomass to deposits formation during combustion, and reduce bed agglomeration in fluidized bed combustion and gasification processes. Washing out alkaline salts from the biomass allows the amount of chlorine, which occurs in the biomass in the form of alkaline potassium and sodium chlorides to be significantly reduced. In this way, the corrosion aggressiveness of biomass can be significantly reduced.

When considering the soaking operation as a method for improving the quality of plant biomass (especially green biomass) as a potential fuel, it should be remembered that it involves the use of significant amounts of energy, i.e. water and the need to dry the biomass before its further use. The whole operation will therefore depend not only on the effective enhancement of biomass properties but also on the possibility of obtaining energy required for this purpose. The implementation of the new Law on the quality of solid fuels for the household sector and small consumers is also of great importance. Its implementation will allow low-quality fuels to be eliminated, and, as a consequence, boilers not meeting the emission standards (Mirowski and Maczuga 2017). The enhancement of straw properties for the production of high quality molded fuels and the associated energy expenditure is therefore economically, as well as environmentally justified.

This study was funded by Statutory Research of the AGH University of Science and Technology No. 11.11.210.373.

\section{References}

BLOMBERG, T.E. 2007. Free alkali-index for optimizing the fuel mixture in biomass co-firing. ECI Symposium Series, Volume RP5: Proceedings of 7th International Conference on Heat Exchanger Fouling and Cleaning - Challenges and Opportunities, Editors Hans Müller-Steinhagen, M. Reza Malayeri, and A. Paul Watkinson, Engineering Conferences International, Tomar, Portugal, July 1-6. 
BÜHLE et al. 2014 - BÜHLE, L., DÜRL, G., HENSGEN, F., URBAN, A. and WACHENDORF, M. 2014. Effects of hydrothermal conditioning andmechanical dewatering on ash melting behaviour of solid fuel produced from European semi-naturalgrasslands. Fuel Vol. 118, pp. 123-129.

Davidsson et al. 2002 - Davidsson, K.O., Koresgren, J.G., Pettersson, J.B.C. and JAglid, U. 2002. The effects of fuel washing techniques on alkali release from biomass. Fuel Vol. 81, No. 2, pp. 137-142.

DZIK, T. and RozWADOWSKI, A. 2012. Methods of selecting components of composite solid fuels for the purpose of gasification (Metodyka doboru skladników kompozytowych paliw statych dla celów zgazowania). Polityka Energetyczna - Energy Policy Journal Vol. 15, Iss. 3, pp. 169-180 (in Polish).

GolińsKi et al. 2014 - Goliński, P., DASZKiewiCZ, J., GolińSKA, B. and CZERwiŃSKi, M. 2014. New technological solutions - a better use of meadow biomass (Nowe rozwiazania technologiczne - lepsze wykorzystanie biomasy tąkowej). Czysta Energia Vol. 9, pp. 38-41 (in Polish).

HANSEN et al. 2000 - Hansen, L.A, Nielsen, H.P., FrandSEN, F.J, DAm-Johansen, K., Horlyck, S. and KARLSSON, A. 2000. Influence of deposit formation on corrosion at a straw-fired boile. Fuel Processing Technology Vol. 64, Iss. 1, pp. 189-209.

JENKINS et al. 1996 - JENKINS, B.M., BAKKER, R.R. and WEI, J.B. 1996. On the properties of washed straw. Biomass and Bioenergy Vol. 10, No. 4, pp.177-200.

MAC AN BHAird et al. 2014 - MAC An Bhaird, S.T, WAlsh, E., HEMMingWay, P.L., MaglinaO, A.L., CAPAREDA, S.C. and MCDONNELL, K.P. 2014. Analysis of bed agglomeration during gasification of wheat straw in a bubbling fluidised bed gasifier using mullite as bed Material. Powder Technology Vol. 254, s. 448-459.

MirowsKi, T. and MACZugA, R. 2017. Legal regulation in the household sector in Poland on the use of solid fuels and boilers up to $500 \mathrm{~kW}$. Zeszyty Naukowe Instytutu Gospodarki Surowcami Mineralnymi i Energia Polskiej Akademii Nauk No. 97, s. 33-42 (in Polish).

Persson et al. 2007 - Persson, K., Brostrom, M., CArlsson, J., Nordin, A. and Backman, R. 2007. High temperature corrosion in a $65 \mathrm{MW}$ waste to energy plant. Fuel Processing Technology Vol. 88, No. 11-12, pp. 1178-1182.

PRONOBIS, M. 2005. Evaluation of the influence of biomass co-combustion on boiler furnace slagging by means of fusibility correlations. Biomass and Bioenergy 28, 4, pp. 375-384.

RICHTER et al. 2011 - RICHTER, F., FRICKE, T. and WACHENDORF, M. 2011. Influence of sward maturity and pre-conditioning temperature on the energy production from grass silage through the integrated generation of solid fuel and biogas from biomass (IFBB): 1 . The fate of mineral compounds. Bioresource Technology 102, 7, pp. 485-4865.

RozWADOWSKI, A. and DZIOK, T. 2017. Changes in the chemical composition of ash and the enhancement of energy properties of cereal straw as a result of its multiple water washing (Zmiana sktadu chemicznego popiołu i poprawa właściwości energetycznych słomy zbożowej w wyniku jej wielokrotnego moczenia w wodzie). Polityka Energetyczna - Energy Policy Journal Vol. 20, Iss. 1, pp. 117-134 (in Polish).

RYBAK, W. 2006. Combustion and co-combustion of solid biofuels (Spalanie $i$ wspótspalanie biopaliw statych). Publishing house of the Wroclaw University of Technology, Wrocław 2006 (in Polish).

ŚCIĄŻKO et al. ed. 2007 - ŚCIĄŻKO, M., ZuWAŁA, J. and PrONOBIS, M. 2007. Co-firing of biomass and alternative fuels in the energy sector (Wspótspalanie biomasy i paliw alternatywnych $w$ energetyce), Publishing house of the Institute for Chemical Processing of Coal and Silesian University of Technology, Zabrze-Gliwice, 363 pp. (in Polish).

SKRĘTA, M. 2012. Green forest biomass trade (Obrót zielona biomasq leśna). Czysta Energia Vol. 7-8, pp. 30-32 (in Polish).

WeRLE, S. 2013. Potential and properties of the granular sewage sludge as a renewable energy source. Inżynieria Ekologiczna Vol. 33, pp. 156-16. 


\title{
Wpływ procesu wielokrotnego moczenia słomy zbożowej wodą na wskaźniki żużlowania i zanieczyszczenia powierzchni grzewczych kotłów energetycznych
}

\begin{abstract}
Streszczenie
W artykule przedstawiono wyniki badań słomy pozyskanej z dojrzewającej pszenicy, którą poddano procesowi czterokrotnego moczenia w wodzie demineralizowanej. Operację moczenia prowadzono w warunkach laboratoryjnych w temperaturze $20^{\circ} \mathrm{C}$. W wyniku moczenia ze słomy została usunięta część substancji mineralnej, w tym znaczna ilość alkalicznych soli sodu i potasu oraz substancji zawierających siarkę i fosfor. Proces moczenia w wyraźny sposób wpłynął na zmianę składu chemicznego popiołu otrzymanego z preparowanej wodą słomy, który zwiększył swoją kwasowość. W popiele o $78 \%$ zmalała zawartość $\mathrm{Na}_{2} \mathrm{O}$, o $60 \%$ zawartość $\mathrm{K}_{2} \mathrm{O}$, do $80 \%$ wzrósł natomiast udział nierozpuszczalnego w wodzie, kwasotwórczego $\mathrm{SiO}_{2}$. W konsekwencji korzystnie zmieniły się wartości wskaźników, za pomocą których oceniana jest skłonność słomy do deponowania zanieczyszczeń podczas spalania i zgazowania. Już w wyniku dwukrotnego moczenia indeks alkaliczności AI przyjmował wartość sugerującą, że paliwo to nie powinno sprawiać trudności podczas spalania z powodu zwiększonej intensywności żużlowania kotła. Natomiast wskaźnik aglomeracji złoża $B A I$ bezpieczną wartość wskazującą na niewielkie prawdopodobieństwo wystąpienia zjawiska aglomeracji złoża podczas spalania lub zgazowania fluidalnego osiągnął po trzecim cyklu moczenia słomy. Trzeci z ocenianych wskaźników, Fouling-Index Fu nie osiągnął wprawdzie wartości wskazującej na brak skłonności paliwa do deponowania zanieczyszczeń podczas spalania, ale w wyniku czterokrotnego moczenia nastąpiła $80 \%$ redukcja jego początkowej wartości. Ostatni z analizowanych wskaźników, wskaźnik lepkości żużla SR, w trakcie prowadzonego eksperymentu nie zmieniał swojej wartości, która dla zarówno dla słomy surowej, jak i po kolejnych cyklach moczenia, wskazywała, że paliwo to powinno charakteryzować się małą skłonnością do odkładania żużlu podczas spalania.
\end{abstract}

SŁOWA KLUCZOWE: słoma zbożowa, moczenie wodą, popiół, alkalia, żużlowanie 
